\title{
Combined microstructural analysis and in-situ U-Pb chronology of baddeleyite within shergottites
}

\author{
LEANNE G STADDON ${ }^{1}$, JAMES R DARLING ${ }^{1}$, WINFRIED \\ H. SCHWARZ ${ }^{2}$, NATASHA R STEPHEN ${ }^{3}$, SHEILA \\ SCHUINDT $^{1}$, JOSEPH DUNLOP ${ }^{1}$ AND KIMBERLY T. TAIT ${ }^{4}$ \\ ${ }^{1}$ University of Portsmouth \\ ${ }^{2}$ Universität Heidelberg \\ ${ }^{3}$ University of Plymouth \\ ${ }^{4}$ Royal Ontario Museum \\ Presenting Author: leanne.staddon@port.ac.uk
}

Baddeleyite (monoclinic; $m-\mathrm{ZrO}_{2}$ ) is a widespread and important chronometer within shergottites and broader planetary materials, yet the integrity of $\mathrm{U}-\mathrm{Pb}$ isotope compositions during shock metamorphism are poorly constrained. While experimental studies indicate robust $\mathrm{U}-\mathrm{Pb}$ isotope systematics up to $\sim 57 \mathrm{GPa}$ [1], shocked baddeleyite within terrestrial [2] and martian [3,4] lithologies document partial to complete age resetting. $\mathrm{Pb}$ loss is closely linked to baddeleyite microstructure $[2,4,5]$, formed by reversion from meta-stable orthorhombic $\left(o-\mathrm{ZrO}_{2}\right)$ polymorphs at $\geq 3.3 \mathrm{GPa}[6]$. Here, we combine microstructural analyses and insitu U-Pb chronology of baddeleyite in four enriched shergottites: Zagami, NWA 7257, NWA 8679 and Tindouf 002.

Our study documents micro-scale structural variability within baddeleyite, and widespread reversion from $o-\mathrm{ZrO}_{2}$. Plastically deformed magmatic twin relationships are rarely preserved, with most baddeleyite yielding poor crystallinity. These quasiamorphous microstructures [4] document partial to complete reversion from $o-\mathrm{ZrO}_{2}$ at low post-shock temperatures (Zagami; $\leq 220{ }^{\circ} \mathrm{C}$ [7]) that inhibited nucleation of reverted $m-\mathrm{ZrO}_{2}$. Higher post-shock temperatures allow micron-scale nucleation of $m-\mathrm{ZrO}_{2}$; these structures are observed within Tindouf 002 and rarely within NWA 8679. Nascent recrystallisation of Tindouf 002 baddeleyite is observed in areas of increased shock melting.

Critically, we observe no link between baddeleyite microstructure and $\mathrm{U}-\mathrm{Pb}$ isotopic compositions, with data forming discordia indicative of closed system U-Pb behaviour. In contrast to previous studies $[2,3,4]$, this indicates that post-shock heating was of insufficient magnitude and longevity to induce resolvable $\mathrm{Pb}$ mobility, and that phase heritage alone does not result in $\mathrm{U}-\mathrm{Pb}$ isotopic disturbance. We therefore present new crystallisation ages for NWA 7257, NWA 8679 and Tindouf 002, confirm the previous U-Pb baddeleyite age of Zagami, and highlight the potential of baddeleyite as a robust $\mathrm{U}-\mathrm{Pb}$ chronometer within a wide range of planetary materials.

[1] Niihara, T. et al. (2012), EPSL 341-344, 195-210. [2] White, L. F. et al (2017), Nat. Comms. 8, 15597. [3] Moser, D. E. et al. (2013), Nature 499, 454-457. [4] Darling, J. R. (2016), EPSL 444, 1-12. [5] White L. F. et al. (2018), Geology 46(8), 719- 722. [6] Takagi, S. et al. (2020), GRL 47, in press. [7] Fritz, J. et al. (2005), MAPS 40(9-10), 1393-1411. 